\title{
Membaca Pendidikan Islam di Era Disrupsi: Perspektif Strukturalisme Transendental
}

\author{
Khairul Umam* \\ Institut Agama Islam Negeri Jember
}

\author{
Keywords: \\ Islamic Educatian, \\ Disruption Era, \\ Structuralism Transcendental
}

\section{Kata Kunci:}

Pendidikan Islam,

Era Disrupsi, Strukturalisme

Transendental

\section{*Correspondence Address:}

khairulumam@iain-jember.ac.id

\begin{abstract}
The era of disruption requires the human life to be no longer linear and has become difficult to predict. The choice is only to move by innovating or being quiet as a spectator. As one of the important elements of Islam, Islamic Education is required to be able to transform and adapt to the era of disruption such as changes in teaching and learning styles, digital literacy, thinking paradigms, the behavior of educators and students to make innovative institutional management, goes hand in hand with digital technology dimensions take place. The main problem is that the effort is allegedly believed to change Islamic education towards a materialistic structure. This study simplifies the analysis of Islamic education in the era of disruption by using the method as well as the transcendental structuralism paradigm introduced by Kuntowijoyo. The structure of Islamic education has met the characteristics of: 1) the totality of the elements possessed; 2) the changes as a strength forming structure, as well as; 3 ) independencies system.
\end{abstract}

\begin{abstract}
Era disrupsi meniscayakan kehidupan manusia tidak lagi linear dan susah diprediksi. Pilihannya hanya bergerak dengan berinovasi atau diam menjadi penonton. Sebagai salah satu elemen penting Islam, Pendidikan Islam dituntut untuk mampu bertransformasi dan beradaptasi dengan era disrupsi seperti perubahan gaya belajar-mengajar, literasi digital, paradigma berfikir, perilaku pendidik maupun peserta didik hingga manajemen lembaga yang inovatif, liniear dengan dimensi-dimensi teknologi-digital yang tengah terjadi. Problem utamanya adalah upaya tersebut disinyalir akan merubah pendidikan Islam ke arah struktur yang bersifat materialistis. Tulisan ini secara simplifikatif menganalisa pendidikan Islam di era disrupsi dengan menggunakan metode sekaligus paradigma strukturalisme transendental yang diperkenalkan oleh Kuntowijoyo. Struktur pendidikan Islam telah memenuhi ciri: 1) totalitas unsur yang dimiliki; 2) perubahan sebagai kekuatan pembentuk struktur, serta; 3) kemandirian sistem.
\end{abstract}

\section{Pendahuluan}

Munculnya gagasan revolusi industri 4.0 mulai beberapa tahun silam di Jerman telah banyak mengispirasi banyak negara untuk mengadopsi hal yang sama. Pemerintah Indonesia sendiri telah memperkenalkan roadmap pergerakan industri nasional dengan jargon
'Making Indonesia 4.0'. Era ini ditandai oleh pergeseran segala aktivitas manusia ke dunia digital dan hubungan manusia dengan mesin.

Realitasnya kemajuan ilmu pengetahuan dan teknologi telah menghasilkan pola hidup yang serba instan sebagai akibat dari melimpahnya sumber daya dan fasilitas teknologi, 
koheren dengan dasar pengembangan ilmu dan penemuan teknologi itu sendiri -yang secara sederhanaberfungsi sebagai alat bantu untuk memudahkan hidup manusia.

Kondisi tersebut berdampak positif bagi masyarakat yang semakin hanyut dalam kemudahan-kemudahan beraktivitas tanpa

khawatirakanketerbatasan-

keterbatasan. Sementara hal ini juga cenderung menarik manusia pada budaya materialismedan bergaya hedonistik.

Dalam euforia materialisme manusia terjebak ke dalam satu aktifitas pemujaan yang ideologistik karena ia lebih banyak tidak disadari atau disadari namun tidak bisa menolak. Istilah populernya 'maju kena mundur kena'. Manusia semakin lama terkurung oleh situasi dan kondisi di mana materi menjadi pusat dari pemenuhan kebutuhan yang paling utama. Pada titik inilah manusia terkurung oleh dimensi materi tanpa makna sehingga Herbert Marcus menjuluki manusia sebagai one dimentional man, manusia yang hanya berdimensi satu, yakni dimensi material saja. ${ }^{1}$

Apa yang dikatakan Marcus merupakan kritik terhadap manusia modern yang terpenjara oleh materialisme dan menegasikan dirinya dari makna hidup dan kehidupan bahkan kesadaran akan kebutuhan yang bersifat religi. Spirit yang bersifat transenden tergantikan oleh spirit materialisme. Kritik tersebut sangat beralasan karena pada zaman modern ini semua lini kehidupan lebih cenderung diukur hanya dengan melimpahnya materi, dan semakin hari

1 Marcus, Herbert, Manusia Satu Dimensi(Yogyakarta: Bentang, 2000), 177 kehilangan makna serta tujuan hidup yang sebenarnya.

Dampak logisnya, dalam konteks pendidikan, visi, misi dan tujuan Lembaga Pendidikan saat ini juga dianggap cenderung terjebak ke dalam praktek penyelenggaraan Pendidikan yang materialistis, tidak terkecuali hal ini juga menggejala di dalam sebagian praktik pendidikan Islam. Kecenderungan itu minimal dapat dibaca dari indikasi manajemen dan pemenuhan output Pendidikan yang bersifat kuantitatif meterialistik daripada moral-spiritualistik. Hal ini berefek pada lahirnya fenomena peserta didik yang menghalalkan segala cara untuk mendapatkan nilai Pendidikan yang dianggap baik secara kuantitatif, sementara kurang memperhatikan makna nilai kualitatif dari proses pembelajaran dan Pendidikan yang mereka alami di Lembaga Pendidikan secara umum.

Menurut Budi Hardiman cengkraman materialisme dalam setiap ranah kehidupan modern saat ini disebabkan oleh gerakan penindasan dan pemaksaaan struktur kehidupan modern yang dilakukan oleh orangorang materialis-positivistik terhadap kemanusiaan. $^{2}$ Modernitas dengan segala variannya memaksa manusia, secara ideologis-hegemonis, mengikuti kehendaknya melalui wajah sains yang berparadigma materialisme radikal plus kapitalisme. Positivisme menjadi ideologi yang kokoh memenjarakan kepercayaan manusia dalam masalah pengukuran dan penilaian Pendidikan, yang kemudian dipuja dan diposisikan sebagai "Tuhan" atau agama baru bagi manusia.

Kuatnya ideologi materialisme menyentuh berbagai lini kehidupan

2 Hardiman,F.Budi,Kritik Ideologi

Pertautan Pengetahuan dan Kepentingan (Yogyakarta: Kanisius, 1993), 60 
pada dasarnya adalah ancaman sekaligus tantangan yang serius bagi penyelenggaraan pendidikan Islam yang sarat akan nilai-nilai (value bond) dan berorientasi immaterial. Dampak yang sangat terasa adalah masyarakat menganggap lembaga pendidikan Islam sebagai lembaga kuno (baca: terbelakang) dengan manajemen mutu yang tidak jelas dan sulit diukursecara kuantitatif-materialistik.

Terlepas dari asumsi kekunoan, pendidikan Islam secara tradisional mengejawantahkan orisinalitas identitasnya sebagai sebuah sistem yang terstruktur dengan mengedepankan nilai religius yang bersifat transenden dan mewujudkan diri sebagai lembaga kontra hegemoni bagi ideologi kehidupan modern yang serba materialis.

Selain itu Secara struktur pendidikan Islam dapat menunjukkan bahwa tidak semua perubahan merupakan hal baik, meski ia akomodatif terhadap perubahan.Transendentalisme nilai tidak dapat diubah oleh meterialisme sebagaimana ideologi manusia modern oleh karena kekuatan nilai yang dibawanya.

Dengan demikian, meminjam pemikiran Kuntowijoyo, pendidikan Islam yang bercorak tradisionalisreligius dapat dipahami melalui struktur yang melampaui (transenden).Dengan struktur tersebutlah pendidikan Islam mampu beradaptasi dengan perubahan global, tanpa harus berubah atau kehilangan struktur dasarnya sebagai sistem pendidikan berbasis nilai-nilai transenden dari agama.

Lebih jauh secara mendasar pendidikan Islam yang bersumber dari nilai-nilai religius dan berpadu dengan nilai kearifan lokal dianggap sesuai dengan kebutuhan masyarakat tradisional, meski juga masih dianggap perlu melakukan pembenahan system penguatan kelembagaan agar tidak tercerabut ke dalam akar budaya yang negatif sebagaimana yang telah dibawa dan menjadi dampak dari globalisasi teknologi dan informasi di era millenial ini.

Tulisaninisecarasimplifikatifmem bahaspendidikanIslamdalam perspektifstrukturalisme transendental Kuntowijoyo. Perspektif ini digunakan untuk menganalisa pendidikan Islam sebagai sebuah struktur dan bagaimana identitasnya di era disrupsi yang penuh dengn tantangan sekularisme, liberalisme dan materialisme.

\section{Strukturalisme Transendental}

Tidak dapat dinafikan bahwa strukturalisme hingga kini tetap dapat dijadikan dasar dan alat dalam menganalisa sistem, sebab konsepkonsep apapun selalu terbuka dan berkaitan dengan sistem dan struktur yang melingkupinya. Hal inilah yang kemudian menginspirasi Kuntowijoyo dalam membahas Islam sebagai sebuah struktur dengan pendekatan strukturalisme transendental.

Suatu Sistem selalu berisi unsurunsur yang saling terkait antara satu dengan lainnya dan tidak dapat dipisah. Struktur akan tampak dan terbuka untuk dipahami dengan mudah dari sistem itu sendiri meski struktur tidak mesti harus dipahami dari sistem.

Sebagai contoh, secara sistem, pendidikan memiliki unsur-unsur utama seperti guru, murid, materi (sarana-prasarana), metode atau strategi dan tujuan. Masing-masing unsur tersebut tidak dapat dipisahkan karena adanya keterikatan antar semua unsurnya. Sementara keterikatan merupakan salah satu elemen dari terbentuknya sebuah struktur. 
Strukturalisme berasal dari kata struktur (menyusun) yang secara sederhana berarti pandangan mengenai susunan-susunan sesuatu. Pada dasarnya struktur dan strukturalisme meliputi bidang yang sangat luas, seperti sosiologi, antropologi, ilmu politik, linguistik, dan kritik sastra. Strukturalisme sendiri merupakan gerakan pemahaman yang memandang bahwa di dunia ini sistem selalu memiliki struktur dan untuk dapat memahaminya membutuhkan pendeka-tan pemahaman secara struktur pula.

Istilah transendental berasal dari kata transenden yang berarti menonjolkan hal-hal yang bersifat kerohanian hal yang abstrak. Namun dalam perspektif Kuntowijoyo, lebih dimaknai dengan arti 'melampaui', yakni melampaui apa yang dapat dialami manusia. Istilah strukturalisme transendental berarti merujuk pada paham tentang susunan sesuatu yang bersifat melampaui pengalaman manusia. Konsep ini tidak melihat apa yang tampak di permukaan susunan, tetapi lebih pada apa yang ada di balik susunan tersebut.

Jean piaget adalah tokoh strukturalisme yang menyebutkan bahwa struktur terdiri atas tiga ciri pokok, yakni: 1) wholeness (keseluruhan); 2) transformation (perubahan); 3) self regulation (mengatur diri sendiri).

Keseluruhan (wholeness) terdiri dari unsur-unsur dasar yang membentuk struktur secara keseluruhan. Wholeness merupakan rangkaian unsur yang membentuk system, dapat diidentifikasi dan menjadi dasar dari prinsip yang ditampakkan ke permukaan. Dimensi wholeness ini harus saling menampakkan keterpaduan dan keberkaitan (inter-connettedness) antara satu unsur dengan lainnya, sebab keberkaitan inilah esensi dari keseluruhan struktur. Sebuah struktur tidak terbentuk melalui unsur-unsur yang independent atau terlepas antara satu dengan lainnya. Lebih jauh unsurunsur struktur terikat secara koheren(terpadu). Oleh karenanya masing-masing elemen struktur tunduk pada aturan atau hukum yang berlaku menurut sistem.

Dengan demikian pada dasarnya struktur tersusun secara lengkap dari kumpulan unsur-unsur yang tidak saling melepaskan diri antara satu dengan lainnya. Ada perbedaan antara keseluruhan dengan unsur-unsurnya.

Unsur-unsur dari suatu struktur tunduk kepada hukum yang mengatur keseluruhan system itu. Hukum yang mengatur suatu struktur tidak dapat disusutkan dalam penjumlahan dari hukum yang mengatur satu demi satu unsur-unsurnya. Unsur-unsur tidak berdiri sendiri secara terpisah tetap menjadi milik suatu struktur.

Perubahan (transformation). Struktur tidaklah bersifat tetap, namun juga berubah secara dinamis dengan menyesuaikan kondisi yang ada. Perubahan terebut bukan berarti merusak tatanan struktur yang telah ada, namun lebih kepada penambahan unsur-unsur (lebih non-primier) sehingga terbentuk struktur baru.

Mengatur diri sendiri (selfregulation). Penambahan unsur-unsur baru dalam sebuah struktur terjadi di dalam struktur itu sendiri dan tidak ada hubungannya dengan perubahan atau penambahan unsur di luar struktur. Namun penambahan-penambahan tersebut fungsinya bukan untuk mengubah struktur secara mendasar, tetapi lebih kepada memelihara struktur sehingga mampu beradaptasi dengan perubahan-perubahan yang terjadi di luar dirinya. 
\begin{tabular}{lcr}
\multicolumn{1}{c}{ Istilah } & strukturalisme & tran- \\
sendental & diperkenalkan & oleh \\
Kuntowijoyo & (seorang Ilmuwan dan \\
Budayawan & Indonesia) & untuk \\
menggambarkan & bahwa & proses
\end{tabular} kehidupan ini berjalan karena adanya gerak struktur yang tersembunyi dan bersifat melampaui apa yang tampak di permukaan. Asumsinya bahwa meski gerak kehidupan ini tampak seolah tidak beraturan namun dalam sisi terdalam ia berjalan menurut struktur yang tersusun rapi, tidak berubah dan berjalan secara mekanis menurut nilainilai yang general. ${ }^{4}$ Nilai-nilai general yang dimaksud dapat berupa ideologi yang menjadi motor penggerak semua struktur. Nilai general inilah yang seharusnya bersifat transenden agar manusia tidak terjebak pada materialisme dan kapitalisme.

Gagasan strukturalisme transendental Kuntowijoyo berangkat dari pemikiran bahwa Islam dengan nilainilai yang terkandung dalam teks (AlQur'an dan al-Hadits) dimaknai secara general dan terstruktur karena sesuai dengan konteks kemanusiaan, baik di jaman lampau, dan dapat diterapkan ke dalam konteks kehidupan saat ini dan di mana saja meski nilai-nilai tersebut telah melewati masa berabad-abad. Menurut hemat penulis, teks-teks tersebut juga dapat diterapkan ke dalam konteks Pendidikan Islam yang tidak terlepas dari nilai-nilai transenden.

\section{Pendidikan Islam}

Konsep pendidikan Islam memiliki pembahasan yang sangat luas. Oleh karenanya ada baiknya kita

\footnotetext{
${ }^{3}$ Sebutan struktur transendental dan metodenya telah disunggunga dalam Kuntowijoyo, Paradigma Islam: Interprestasi unuk Aksi (Jakarta: Mizan, 1991)

4 Kuntowijoyo, Muslim Tanpa Masjid (Jakarta: Mizan, 2001), 10
}

mengenal beberapa konsep pendidikan Islam yang kemudian dilanjutkan dengan kajian strukturalisme transendental yang melingkupinya.

Secara umum, konsep pendidikan Islam tidak terlepas dari beberapa istilah seperti at-Tarbiyyah (term yang berhubungan dengan pengetahuan tentang Tuhan atau $a r-R a b b)$, at-Ta'lim (term yang berhubungan dengan ilmu pengetahuan, kreativitas, komitmen yang tinggi untuk mengembangkan ilmu, serta sikap hidup yang menjunjung tinggi nilai-nilai ilmiah), dan at-Ta'dib (term yang berhubungan dengan moralitas pengetahuan atau pengamalan ilmu, atau perpaduan ilmu dan amal).

Muhaimin berpendapat bahwa konsep Pendidikan Islam dapat dipahami melalui beberapa perspektif berikut:

1. Pendidikan menurut Islam atau pendidikan yang berdasarkan Islam, yaitu pendidikan yang dipahami dan dikembangkan serta disusun dari ajaran dan nilai-nilai fundamental yang terkandung dalam sumber dasarnya, yaitu Al-Qur'an dan Sunnah;

2. Pendidikan keislaman atau pendidikan agama Islam, yakni upaya pendidikan agama Islam atau ajaran Islam dan nilainilainya, agar menjadi way of life (pandangan dan sikap hidup) seseorang;

3. Pendidikan dalam Islam, atau proses dan praktik penyelenggaraan pendidikan yang berlangsung dan berkembang dalam sejarah umat Islam. ${ }^{5}$

Secara umum dapat dimengerti bahwa yang dimaksud Pendidikan Islam merupakan rangkaian proses kegiatan yang dilaksanakan secara sadar, terencana, sistematis, berkesinambungan, berpola, dan terstruktur untuk membimbing,

5 Muhaimin, Wacana Pengembangan Pendidikan Islam(Yogyakarta: Pustaka Pelajar,2005), h. 23-24. 
mengarahkan, membina, mendidik, serta melatih peserta didik dengan nilai-nilai ataupun keterampilan yang sesuai dengan ajaran atau nilai agama Islam. Tujuannya adalah untuk mencapai insan kamil (manusia sempurna) dan makhluk yang diridhai oleh Allah SWT.

Secara konseptual, pendidikan Islam didasarkan pada prinsip-prinsip berikut: 1) Agama Islam memandang bahwa pendidikan merupakan elemen penting dalam perintah beragama dalam rangka menumbuhkan keimanan yang kuat. Secara ekstrinsik Al-qur'an dalam surat al-'Alaq ayat 1-5 dimaknai agar setiap muslim harus belajar dengan melakukan kajian, analisis, penelitian dengan observasi, eksplorasi, eksperimentasi dan riset secara menyeluruh dan komprehensif guna menyingkap makna; 2) Oleh karenanya pendidikan dianggap sebagai implementasi ibadah kepada Allah; dan 3) Allah menjanjikan derajat yang sangat tinggi kepada orang yang beriman dan memiliki ilmu pengetahuan, di mana keduanya tidak mungkin dicapai manusia tanpa melaksanakan proses pendidikan (lihat surat al-Mujadalah: 11 dan an-Nahl: 43); 4) Bahwa pendidikan tersebut bagi seluruh muslim wajib dilaksanakan sepanjang hayat (life long education) karena manusia adalah makhluk yang berproses untuk menuju kesempurnaan hidup (insan kamil).

\section{Metode}

Sesuai judul tulisan ini, metode dalam memahami Pendidikan Islam menggunakan paradigma strukturalisme transendental. Menurut Kuntowijoyo strukturalisme biasa digunakan dalam ilmu-ilmu empiris. Pendidikan Islam sendiri memang memiliki dimensi empiris, namun tidak semuanya empiris, terutama bagian

doktrin keagamaannya yang bersifat religius. Penggunaan pendekatan dan paradigma strukturalisme untuk memahami Pendidikan Islam sebagai ajaran agama yang bersifat strukturalis. Tujuan penulis adalah bagaimana mengidentifikasi nilai-nilai universal dalam pendidikan Islam berdasar teksteks lama (Al-Qur'an-Hadits) terkait pendidikan Islam pada konteks sosial masa kini di era disrupsi ini tanpa mengubah strukturnya.

\section{Pendidikan Islam sebagai Struktur}

Bila Pendidikan Islam dipandang sebagai sebuah sistem, maka Pendidikan Islam terdiri dari beberapa unsur yang membentuk strukturnya secara lengkap, diantaranya adalah: pendidik, peserta didik, sarana dan prasarana, metode/strategi dan tujuan pendidikan. Dengan demikian syarat Pendidikan Islam dapat dibaca sebagai sebuah struktur telah terpenuhi.

Pertama,

(keseluruhan)Pendidi-kan Islam mengikat kelima unsur utama di atas menjadi sebuah sistem.Sistem tidak akan berjalan jika salah satu elemennya tidak berjalan atau tidak ada.

Masing-masing unsur pada dasarnya berdiri sendiri dengan nilainilai yang mengikiat secara mandiri, namun semua elemen tersebut saling mengikat satu dengan lainnya.

Dengan adanya semua unsur tersebut tidak menjadikan Pendidikan Islam berjalan dengan baik, tetapi keseluruhan itu perlu ada nilai pengikat. Nilai guru, murid, materi, metode tujuan, masing-masing memiliki nilai tetapi masing-masing saling mengikat dengan nilai general sebagai sebuah struktur yang hidup.

Kedua, transformation (perubahan bentuk). Sebagai sebuah sistem, pendidikan Islam tidak berjalan statis baik secara sejarah maupun model atau 
bentuk penyelenggaraannya. Misalnya, dulu Pendidikan Islam selalu identik denganketradisionalannya. Model pembelajarannya menggunakan sistem halaqoh, ribath, dan semacamnya, sebagaimana selama ini dikenal diPendidikan Islam dan lembaga pendidikan tradisional sejenis. Saat ini pendidikan Islam telah mengenal $\mathrm{dn}$ menerapkan pola dan model 'modern' dengan sistem sekolah seperti madrasah. Secara struktur kurikulum, struktur pengelola, struktur sistem, struktur tujuan juga telah banyak berubah. Dulu tujuan pendidikan Islam lebih cenderung untuk mentransformasi nilai (mengokohkan akidah), saat ini pengokohan akidah tetap namun dibarengi dengan pengokohan Ilmu pengetahuan dan teknologi. Bahkan, secara kelembagaan, jika dahulu murni menjalankan pendidikanan sich, kemudian berubah menjadilembaga dakwah dan sosial hingga lembaga yang digunakan untuk kepentingan-kepentingan politis oleh orang-orang tertentu. Dengan kata lain lembaga Pendidikan Islam digunakan oleh orang-orang tertentu untuk menyisipkan agenda (kasus penistaan agama dengan soal-soal ujian, kasus ajaran-ajaran tertentu oleh kelompokkelompok tertentu).

Di lain hal, dalam sejarah sosial pendidikan Islam, sistem pendidikan Islam berkembang beriringan dengan perkembangan zaman, berintegrasi dengan sistem-sistem pendidikan modern secara dinamis dan fleksibel dengan sistem dan lembaga pendidikan lainnya tanpa kehilangan identitas dan karakteristik dasarnya, yang bertumpu pada prinsip terintegrasi antara teosentrisme (ketuhanan) dan antrophosentrisme (kemanusiaan). ${ }^{6}$

6 Lihat Abd. Rahman Assegaf. Filsafat Pendidikan Islam, Paradigma Baru Pendidikan
Tipikal pendidikan Islam ini menjadikannya sebagai model pendidikan yang dianggap ideal. Berbeda dengan pendidikan ala barat yang hanya berorientasi pada dimensi humanisme kultural, beraraskan pada pengembangan akal manusia dan moral hanya atas dasar prinsip budaya lingkungan dengan nilai-nilai yang melekat di dalamnya. ${ }^{7}$

Secara sederhana, meminjam perspektif Kuntowijoyo pola perubahan sistem pembelajaran dan pendidikan Islamberanjak dari ajaran berbasis mitos (baca: keyakinan/iman), ke fase ideologi (mazhab-mazhab), kemudian ke fase objektifikasi (rasionalisasi pemahaman keagamaan), meski rasionalisasi ini tidak menyeluruh. Setiap fase perubahan tersebut merupakan bentuk ijtihad dan tampak tidak mengubah struktur nilai pengikat struktur general, yakni bersumber dari teks (al Qur'an dan as Sunnah).

Ketiga, mengatur diri sendiri(self regulation). Sebagai sebuah sistem yang memiliki nilai Contohnya tujuan PI adalah untuk mencari ridha Allah, untuk beribadah. Sehingga misi lembaga-lembaga PI meskipun berbeda dalam konsep tujuan lembaganya, tetap arahnya diatur oleh kepentingan nilai mencari ridha Allah, bukan mencari dunia atau semacamnya.

\section{Membaca Pendidikan Islam melalui Strukturalisme Transendental}

Terdapat 3 (tiga) ciri dalam menggambarkan struktur bangunan dari entitas Pendidikan Islam itu sendiri, yaitu: 1) keseluruhan atau totalitas; 2) kekuatan pembentuk

Hadhari Berbasis Integratif Interkonektif (Jakarta; Rajawali Pers. 2011), 219

${ }^{7}$ Ibid, 224 
struktur; dan 3) pertentangan antara dua hal.

1. Struktur keseluruhan atau totalitas (wholeness).

Keseluruhan dapat dipahami dengan melihat unsur-unsur struktur sekaligus keterkaitan (inter-connecttedness) antar unsur yang ada. Keterkaitan ini penting dibahas karena hal itulah yang mencerminkan keseluruhan dengan arti bahwa unsur-unsur yang dimaksud tidak dapat berdiri sendiri. Unsur-unsur Pendidikan Islam seperti yang telah kita ketahui adalah kyai, santri, masjid, asrama dan pengajaran kitab-kitab klasik. Jika boleh menambahkan maka dapat kita identifikasi adanya unsur lain seperti nilai etika atau moral, metode pebelejaran serta tujuan pendidikan yang bersifat transenden seperti beriman sempurna, berilmu luas dan berakhlaq sejati.

Unsur ustadz/guru, santri, masjid, asrama, kitab-kitab, moralitas, metode dan tujuan pendidikan di Pendidikan Islam tidak dapat dipisah. Ustadz/guru sebagai figur utama menjadi teladan moral etis dalam segala aspek kehidupannya bagi para santri, baik keilmuan, sosial, budaya, moral, dan lainnya. Sementara ustadz/guru digambarkan sebagai ulama yang secara ikhlas mentransmisikan ilmu-ilmu agama kepada para santrinya dengan penuh kasih sayang. Realitas ini mampu menciptakan hubungan emosional yang kuat antara kyai dan santri. Hubungan emosional ini tercipta dari suasana Pendidikan Islam yang didukung oleh sarana masjid, asrama, dan pengajaran kitab-kita klasik.
Hubungan emosional antara ustadz/guru dan santri di Pendidikan Islam diwarnai oleh nilai-nilai moral. Menurut al Farabi implementasi nilai moral dapat dilihat dari kemampuan menerapkan ilmu yang didapat ke dalam praktik kehidupan, yaitu ketika kita tahu mengenai sabar dan syukur kemudian kita mampu mengamalkannya. Dalam konteks Pendidikan Islam moral beserta nilai-nilai yang melingkupinya berfungsi sebagai unsur penguat inter-connecttednessdalam keseluruhan unsur dari struktur Pendidikan Islam yang lebih cenderung bersifat transenden.

$$
\text { Persoalan moral di }
$$

Pendidikan Islam adalah persoalan eksistensi kemanusiaan dalam segala aspeknya, baik individu, bermasyarakat, hubungannya dengan Tuhan, dengan sesama manusia dan dirinya, maupun dengan alam sekitarnya, baik dalam bidang sosial, ekonomi, politik, budaya maupun agama. ${ }^{8}$ Lebih dari itu pengamalan ilmu dan nilai moral spiritual dijadikan entitias yang tidak terpisahkan. Masalah moral tidak bisa dilepaskan dengan tekad ustadz/guru dan santri dalam menemukan kebenaran, sebab untuk menemukan dan mempertahankan kebenaran, diperlukan keberanian moral. ${ }^{9}$ Nilai moral bagi Pendidikan Islam bersifat universal karena bersumber dari pemaknaan atas wahyu, sebagaimana esensialisme

8 Musa Asy'arie. Filsafat Islam Sunnah Nabi dalam Berfikir. (Yogyakarta; LESFI.2008), 93

9 Jujun S. Suriasumantri. Filsafat Ilmu Sebuah Pengantar Populer(Jakarta;Pustaka Sinar Harapan. 2002), 235 
memandang nilai suatu ide bersifat permanen. Namun yang berbeda adalah bahwa nilai menurut esensialisme ataupun perennialisme hanya terbatas pada aspek rasio, ide, dan kultural tidak menyentuh wahyu. ${ }^{10}$

Suksesnya pendidikan di Pendidikan Islam dalam melahirkan ulama-ulama bisa jadi terletak pada bukan hanya caranya di/mempelajari tetapi pada proses bagaimana mengantarkan seorang santri mengetahui ilmu (materi) bukan hanya sebatas materi, tetapi juga makna materi itu sendiri. Aksiologi ilmu modern yang ada hanya mengantarkan manusia pada pengetahuan kebendaan, sehingga hal itu tidak mampu menyelesaikan masalah kemanusian dari dulu hingga sekarang.

$$
\text { Pendidikan Islam di }
$$

Pendidikan Islam sarat akan nilainilai moral maupun etis. Nilai etika sangat urgen kaitannya dalam proses pendidikan dan pembelajaran. Pendidikan dan pengajaran bukanlah upaya memenuhi otak anak didik dengan segala macam ilmu, tetapi sekaligus mendidik akhlak dan jiwa mereka. ${ }^{11}$ Hal itu karena tujuan dari pendidikan Islam di Pendidikan Islam adalah menekankan pada tujuan akhir, yakni menghasilkan manusia yang baik (sholih), ${ }^{12}$ dan mencapai

10 Abd. Rahman Assegaf. Filsafat Pendidikan Islam..., 224. Bandingkan dengan Musa Asy'arie. Filsafat Islam....h.95

11 Ibid. h.225. bandingkan dengan Samsul Nizar. Filsafat Pendidikan Islam, Pendekatan Historis, Teoritis dan Praktis. (Jakarta; Ciputat Pers. 2002), 34

12 Syed Muhammad al Naquib al-Attas. Konsep Pendidikan dalam Islam: Suatu Rangka Pikir Pembinaan Filsafat Pendidikan Islam. Terj. Haidar Baqir. (Bandung; Mizan. 1987), 8 kebahagiaan tertinggi, yaitu kebahagiaan yang tidak hanya sebatas kebahagiaan fisik, mental, logik, moral tetapi juga kebahagiaan spiritual, 13

Orientasi pendidikan dan upaya memperoleh ilmu dijadikan bekal kehidupan duniawi dan ukhrawi. Untuk itu tidak hanya sekedar mengandalkan kapabilitas rasional yang bernuansa antroposentris, tetapi ilmu pengetahuan diperoleh juga melalui riyadhah dan mujahadah ${ }^{14}$ untuk mendekatkan diri kepada Allah SWT sebagai Sang Pencipta alam semesta. Model seperti ini tidak dapat dicapai maupun ditransmisikan lewat proses pendidikan dan pembelajaran ekplanasi, penalaran maupun kritisisme intelektual.

Permasalahan mengenai nilai dalam perspektif pendidikan Islam dan barat sangat berbeda. Jika pendidikan Islam lebih mementingkan transendensi maka barat lebih mementingkan sekularismenya. Pendidikan di Pendidikan Islam memandang bahwa nilai moral bukan hanya terbatas pada etika yang bersinggungan dengan manusia dan kehidupannya, yang hanya berpijak atas nilai-nilai sosial, kultural, kemanusiaan yang serba antroposentris, tetapi juga nilai moral yang berhubungan dengan etika manusia terhadap Tuhannya. Nilai moral dalam pendidikan Pendidikan Islam dapat dianggap nilai yang antroposentris sekaligus teosentris, yaitu nilai yang

13 Lihat Mulyadhi Kartanegara. Menembus Batas Waktu. Panorama Filsafat Islam. (Bandung; Mizan. 2005), 70-75

${ }^{14}$ Lihat Mahmud Arif. Pendidikan Islam Transformatif. (Yogyakart; LkiS. 2008), 262 
bersumber dari nilai kemanusiaan (insaniyah) dan nilai ketuhanan (Ilahiyah dan ruhiyah). Nilai kemanusiaan berasal dari potensi dasar manusia yaitu daya cipta, rasa dan karsa yang bersifat dinamis dan temporal (nilai relatif), sedangkan nilai ketuhanan bersumber dari wahyu (kalamullah) dan tanda-tanda ciptaan-Nya (kauni), yaitu nilai yang kekal (nilai absolute) dan bisa diterapkan di semua tempat dan waktu (shalih fi kulli zaman wa makan).

2. Strukturalisme tidak mencari struktur di permukaan tetapi di bawah atau di balik realitas empiris yaitu kekuatan pembentuk struktur (innate structuring capacity).

Kehidupan diPendidikan Islam diwarnai oleh suasanasuasana yang tersimpul dalam apa yang disebut dengan jiwa-jiwa kePendidikan Islaman. Jiwa-jiwa inilah sebagai kekuatan pembentuk struktur Pendidikan Islam yang sulit ditemukan pada lembaga pendidikan lainnya. Jiwa-jiwa tersebut ialah :

a.) Keikhlasan. Bersikap ikhlas, yaitu sikap yang tulus tanpa tendensi dan ditujukan hanya kepada Allah SWT, jiwa ini merupakan cerminan dari tauhid dan akidah yang kokoh. Hidup dipandang sebagai ibadah. Oleh karenanya menjalankan syariat Islam sebagaimana diajarkan oleh ustadz/guru di Pendidikan Islam harus dilaksanakan dengan ikhlas. Menurut Nur Salim di pondok Pendidikan Islam segala perbuatan dan tanggungjawab dilakukan sebagai bentuk ibadah yang murni disyariatkan, baik ibadah kepada Allah (mahdah) maupun ibadah sebagai amal atau perbuatan (ghairu mahdah)dengan didasari pada sikap dan jiwa yang ikhlas tanpa pamrih untuk menegakkan nilai agama. ${ }^{15}$ Keihklasan sendiri dapat dimaknai menerima segala hal yang telah ditetapkan Tuhan kepada manusia. Lebih dari itu ajaran dari ulama atau ustadz/guru dijadikan dipegang secara kokoh tanpa adanya bantahan yang tidak logis. Justeru terkadang ajaran tersebut dianggap sebagai bagian dari implementasi ibadah itu sendiri. Dengan jiwa keikhlasan ini para santri senantiasa dibiasakan untuk mencintai doktrin agama Islam, berdedikasi pada masalah-masalah agama. ${ }^{16}$ Meski demikian keikhlasan para santri dan ustadz/guru tidak diartikan menerima segala nilai yang ada, semisal kezaliman. Nilai keikhlasana dilaksanakan secara proporsional selama tidak menyalahi ruh dari syariat Islam itu sendiri. Dalam contoh keseharian, para ustadz/guru ikhlas mentransmisikan

15 Sugeng Haryanto. Persepsi Santri Terhadap Perilaku Kepemimpinan Ustadz/guru Di Pondok Pendidikan Islam (Studi Interaksionisme Simbolik di Pondok Pendidikan Islam Sidogiri - Pasuruan)Disertasi (UIN Malang, 2011), 302

16 Pradjarta Dirdjosanjoto, Memelihara Umat: Ustadz/guruPendidikan IslamUstadz/guru Langgar di Jawa (Jogjakarta: LKiS, 1999), 141. Lihat juga Abdurahman Wahid, Menggerakan Tradisi: Esai-esai Pendidikan Islam(Jogjakarta: LkiS), 2001 
ilmunya, sementara santri ikhlas dalam menerima semua ajaran ustadz/gurunya tanpa ada beban.

b.) Kesederhanaan.

Hidup sederhana yaitu merupakan refleksi dari sifat dan sikap zuhud, waro', dan qonaah dalam pengertian yang benar dan proporsional. Sederhana bukan berarti miskin, tapi situasional, kondusif dan hikmah. Kesederhanaan para ustadz/guru dan santri tercermin dari sikap tidak berlebihan dalam segala hal. Kesederhaan lebih dijadikan benteng dalam menahan sikap mubazir terkait masalah keduniawian. Bagi Pendidikan Islam sikap berlebihan dianggap sama dengan hal yang memabukkan. Oleh karenanya berlebihan sering dianggap sebagai hal yang haram.

c.) Berdikari atau berjiwa mandiri. Berdikari merupakan berarti tidak menggantungkan diri pada orang lain, tapi memiliki kepribadian utuh dan ideal serta percaya diri (self convidence). Berdikari dalam perspektif ustadz/guru dan snatri tidak dimaknai kepercayaan diri yang berlebihan (over convidence), apalagi terlalu membanggakan diri atau bahkan sombong dan angkuh.

Kemandirian ustadz/guru terlihat dari bagaimana mereka mengorganisir segala tugas dan kewajibannya sebagai figur, suami, guru dan tokoh masyarakat. Demikian juga kemandirian santri terlihat dalam memenuhi kebutuhan hidupnya selama di Pendidikan Islam, mengorganisir kegiatan sehari-hari, belajar mandiri (otodidak) dan lain sebagainya.

d.) Ukhuwah Islamiah, yang dilandasi dengan iman, dimotivasi oleh kebersamaan, persatuan dan kesatuan (togetherness and unity). Pendidikan Islam merupakan lembaga pendidikan yang mampu menciptakan persaudaraan yang kuat antar santri dan ustadz/guru karena mereka datang ke Pendidikan Islam dari berbagai macam latar belakang hidup dalam rangka menuntut ilmu agama sebagai implementasi ibadah. Ilmu agama

e.) Berjiwa bebas, dalam artian merdeka dan bebas berfikir, bebas menentukan sikap. Tentu atas dasar iman, ilmu dan akhlaqul karimah, karena di hutanpun orang tidak akan bebas. Jiwa kebebasan di Pendidikan Islam bermakna bahwa kia dan santri harus merasa merdeka sebagai manusia dalam menjalankan kehidupannya sehari-hari. Hal itu karena diyakini bahwa manusia sejatinya makhluk yang memiliki kebebasan berkehendak sesuai dengan fitrah yang Allah tetapkan kepada manusia. Meski demikian para ustadz/guru dan santri memahami bahwa kebebasan manusia bukanlah kebebasan total karena kebebasan individu memiliki batas sesuai dengan nilai-nilai yang dipedomani dalam hidupnya, baik nilai jasmaniah, spiritualisme dan nilai intelektualisme. Kebebasan di 
Pendidikan Islam dibatasi oleh nilai-nilai agama, nilai kultural, nilai bangsa hingga nilai-nilai moral lainnya.

3. Binary Opposition (pertentangan antara dua hal).

Dalam tataran empiris, keterkaitan antar unsur di dalam struktur bisa berbentuk binary opposition (pertentangan antara dua hal). Pertentangan di dunia Pendidikan Islam dapat dikatakan berasal dari internal dan eksternal Pendidikan Islam itu sendiri. Secara internal pertentangan dalam struktur Pendidikan Islam dapat diidentifikasi dari perbedaan pandangan antara ustadz/guru dengan ustadz/guru lainnya dalam satu Pendidikan Islam, antara santri dengan ustadz/gurunya dalam pemahaman agama (fiqh). Sementara secara eksternal dapat dilihat dari perbedaan pendapat antara masyarakat dengan ustadz/gurudalam memahami realitas social maupun hal-hal bersifat ibadah (fiqh) dan lain-lain, masjid dan gereja, santri dan bukan santri, kyai dan kyai lainnya dan sebagainya.

Dari penjelasan di atas, terdapat struktur yang bersifat transenden i dunia Pendidikan Islam, yang mampu memberikannya kekuatan dalam mempertahankan eksistensinya di tengah arus kehidupan masyarakat Indonesia dengan permasalah sistem pendidikannya. Selebihnya dalam struktur yang transenden tersebut kita juga dapat mengidentifikasi beberapa agendaPendidikan Islamdalam menghadapi tantangan global, di antaranya yaitu:

1. Kesadaran akanperubahan. Sebagian Pendidikan Islam di Indonesia telah mampu melihat adanya perubahan-perubahan global yang terjadi di sekitarnya. Dalam menanggapi hal itu, Pendidikan Islamberupaya membuka diri terhadap realitas sosial yang ada dengan melakukan transformasi di bidang sistem pendidikan. Mereka menyadari bahwa Pendidikan Islam bukanlah satu-satunya lembaga pendidikan yang mengajarkan pendidikan agama (kalau juga mau dikatakan pendidikan agama plus umum). Di luar sistem Pendidikan Islam juga sudah tumbuh subur system pendidikan keagamaan yang tidak kalah maju dengan diterapkannya basis keilmuan imtaq dan iptek seperti Madrasah dan Sekolahsekolah umum bernafaskan agama.

2. Kesadaran kolektif. Orang-orang Pendidikan Islam telah memiliki kesadaran individu bahwa Pendidikan Islam tidak bersifat ekslusif dan tidak terbatas pada kelompok-kelompok tertentu dengan misi-misi tententu yang tidak mencerminkan 'ummatan wahidah'. Meski terdapat kalangan Pendidikan Islamyang terpecahpecah ke dalam kelompok fundamentalis, moderat, liberal dan bahkan secular, sebagian besar Pendidikan Islam memiliki kesadaran atas misi utamanya menegakkan agama Islam. Kesadaran orang-orang Pendidikan Islam bukan hanya sebatas pada pemahamannya atas ideologi hidupnya, tetapi juga pemahaman kolektif untuk menerima dan mengasihi dalam berbagai bidang, baik politik, agama, keyakinan, social, budaya dan ekonomi. Namun yang menjadi masalah menurut Kuntowijoyo, banyak orang mengaku Islam (orang dari Pendidikan Islam) tetapi praktek ekonominya adalah kapitalis. 
Banyak orang mengaku dari kalangan Pendidikan Islam tetapi kesadarannya tidak diikuti oleh prilaku Pendidikan Islam yang menjunjung tinggi keikhlasan, ukhuwah islamiyah sehingga muncul tindak kekerasan terhadap golongan Islam lain.

3. Kesadaran sejarah. Kesadaran individu orang-orang Pendidikan Islamterarah juga pada kesadaran sejarah karena kesadaran mereka akan masa depan tidak hanya dikaitkan dengan tentang masa depan individu masing-masing, teteapi juga masa depan umat apalagi sejarah umat. Kesadaran sejarah dalam hal ini adalah kesadaran individu Pendidikan Islam bahwa Pendidikan Islam itu adalah masalah kolektifitas umat, yang mau tidak mau harus ikut andil dalam menghadapi arus perkembangan sejarah. Hal itu berarti bahwa individu Pendidikan Islamtelah aktif sebagai subjek yang menentukan masa depan sejarah Pendidikan Islam itu sendiri, sejarah ummat, dan sejarah bangsa. Mereka tidak lagi hanya menunggu untuk dikendalikan kekuatan sejarah lainnya seperti sejarah globalisasi sebagai objek.

4. Kesadaran tentang fakta sosial. Fakta social menunjukkan perubahan tatanan nilai yang begitu massive. Berubahnya pola komunikasi dan tata cara belajar manusia di zaman informatif ini telah memberikan cara pandang baru terhadap nilai dan moral kehidupan. Saat ini Pendidikan Islam telah menyadari akan fakto sosial ini. Orang-orang Pendidikan Islamtidak lagi terkejut dalam menghadapi perubahan tatanan nilai yang bersifat melawan arus nilai essensial.Dengan kesadaran itu setidaknya Pendidikan Islam dapat memberikan warna lain dalam mencounter tatanan nilai yang ada di luar realita Pendidikan Islam sendiri.

5. Kesadaran akan masyarakat abstrak. Masyarakat Pendidikan Islam saat ini mulai menyadari bahwa semakin modern peradaban sebuah masyarakat makasemakin abstraklah masyarakat tersebut. Faktanya komunikasi dalam berbagai bidang saat ini telah bergantung pada sistem yang abstrak dan objektif, tidak kepada orang yang kongkret dan subjektif. Komunikasi di tengahtengah masyarakat berlangsung secara lebih efektif melalui simbolsimbolyang abstrak seperti pengetahuan, seni, filsafat. Orangorang telah benar-benar melakukan 'undzur maa qaala wa la tandzur man qaala' lihatlah perkataannya jangan lihat siapa yang mengatakannya. Dunia Pendidikan Islam pun memiliki kesadaran akan hal itu dan bereaksi dengan merekayasa agama, seni dan ilmu agar umat (santri) memiliki kemampuan dakwah yang menguasai symbol-simbol dan sesuai dengan harapan masyarakat yang semakin mengagung-agungkan symbol (abstrak).

\section{Kesimpulan}

Struktur pendidikan Islam terwujud melalui keterikatan antar semua unsur intrinsik yang bersifat transenden (melampaui). Keterikatan tersebut tidak hanya diwakili oleh persamaan fungsi general dari pendidikan Islam, tetapi juga perbedaan yang justru memperkokoh struktur pendidikan Islam itu sendiri, sehingga secara mendasar, dalam perspektif strukturalisme transendental pendidikan Islam secara mendasar telah memiliki kesiapan dalam menghadapi era disrupsi. 


\section{Referensi}

Al-Attas, Syed Muhammad al Naquib, Konsep Pendidikan dalam Islam: Suatu Rangka Pikir Pembinaan Filsafat Pendidikan Islam. Terj. Haidar Baqir, Bandung: Mizan, 1987.

Arif, Mahmud, Pendidikan Islam Transformatif, Yogyakart: LkiS, 2008.

Assegaf, Abd. Rahman, Filsafat Pendidikan Islam, Paradigma Baru Pendidikan Hadhari Berbasis Integratif Interkonektif, Jakarta: Rajawali Pers, 2011.

Asy'arie, Musa, Filsafat Islam Sunnah Nabi dalam Berfikir, Yogyakarta: LESFI.2008.

Dirdjosanjoto, Pradjarta, Memelihara Umat: Ustadz/Guru Pendidikan Islam-Ustadz/Guru Langgar di Jawa, Jogjakarta: LKiS, 1999.

Hardiman,F.Budi,Kritik Ideologi Pertautan Pengetahuan dan Kepentingan, Yogyakarta: Kanisius, 1993.

Haryanto, Sugeng, Persepsi Santri Terhadap Perilaku Kepemimpinan Ustadz/Guru di Pondok Pendidikan Islam (Studi Interaksionisme Simbolik di Pondok Pendidikan Islam Sidogiri - Pasuruan. Disertasi. Malang: UIN Malang, 2011.

Kartanegara, Mulyadhi, Menembus Batas Waktu: Panorama Filsafat Islam, Bandung: Mizan, 2005.

Kuntowijoyo, Muslim Tanpa Masjid, Jakarta: Mizan, 2001.

Kuntowijoyo, Paradigma Islam: Interprestasi untuk Aksi, Jakarta: Mizan, 1991.

Marcus, Herbert, Manusia Satu Dimensi, Yogyakarta: Bentang, 2000.
Muhaimin, Wacana Pengembangan Pendidikan Islam, Yogyakarta: Pustaka Pelajar,2005.

Nizar, Samsul, Filsafat Pendidikan Islam, Pendekatan Historis, Teoritis dan Praktis, Jakarta: Ciputat Pers, 2002.

Suriasumantri, Jujun S., Filsafat Ilmu Sebuah Pengantar Populer, Jakarta: Pustaka Sinar Harapan, 2002.

Wahid, Abdurahman, Menggerakan Tradisi: Esai-esai Pendidikan Islam, Yogjakarta: LKiS, 2001. 